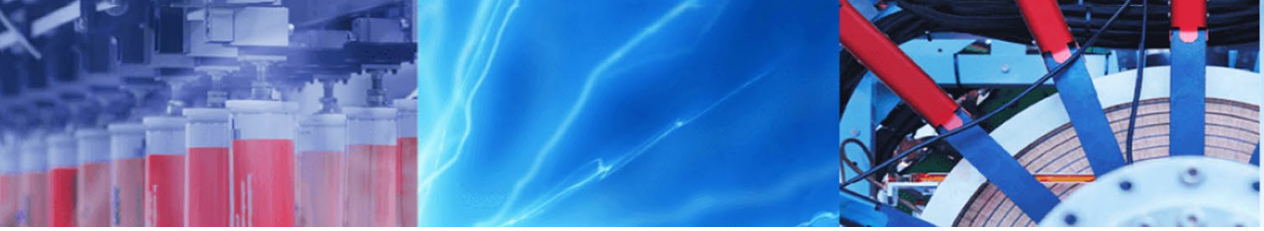

Research Article

\title{
Proposal of precipitation-dissolution models in a channel affected by acid mine drainage in the Iberian Pyrite Belt during torrential rain regimes
}

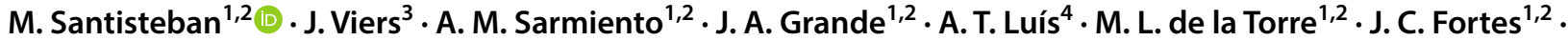 \\ J. M. Dávila ${ }^{1,2}$
}

(c) Springer Nature Switzerland AG 2019

\begin{abstract}
Two sampling points were defined in the Meca River, which receives leachates from the tailings of the Tharsis Mining Complex in the Iberian Pyrite Belt, SW Spain: 'MECA A', which is located at the base of the tailings, and 'MECA B', located downstream at a distance of $14,165 \mathrm{~m} .24 \mathrm{~h}$ of sampling was scheduled for a date in which precipitation intensity would be very high, so observations of the system were undertaken under high flow conditions. The study of the physico-chemical parameters obtained from the analysis of the samples, combined with rainfall data, enabled us to characterise the processes which govern the precipitation-dissolution phenomena along the analysed river, by applying graphic statistical tools, such as the autocorrelation functions, cross-correlation functions and spatial evolution, as well as geochemical modelling tools. The compositional differences between both points are fundamentally due to two phenomena: the first is a consequence of the proximity to the pollutant source, where the waters have not yet evolved, while the second is due to the development of hydrolysis processes in areas further away from the source focus.
\end{abstract}

Keywords Acid mine drainage · Iberian Pyrite Belt · Odiel River · Metals · Pollution

\section{Introduction}

The Iberian Pyrite Belt has been one of the most mined areas since the beginning of civilisation due to the interest aroused by its massive sulphide deposits. With the structural crisis of pyrite as a raw material for producing sulphuric acid, and the decline of the laws and prices of basic metals, among other reasons of financial and environmental nature, a large number of mines were closed [13]. Without environmental legislation forcing mining companies to develop a restoration plan that would integrate the space in question into the natural environment, the mines ceased operations, leaving millions of tons of abandoned waste and unrestored mining activities that are currently potential sources of pollution of the water network running through these areas due to acid mine drainage (AMD) processes.

The incorporation of acid drainage from mining operations into river networks is the main factor responsible for modifying the physico-chemical properties of rivers, increasing the acidity of their waters, their heavy metal and sulphate content, and the concentration of metals in their sediments, until reaching extreme values [13, 21, 33].

M. Santisteban, maria.santisteban@dimme.uhu.es | 1 Department of Water, Mining and Environment, Scientific and Technological Center of Huelva, University of Huelva, 21004 Huelva, Spain. ${ }^{2}$ Sustainable Mining Engineering Research Group, Department of Mining, Mechanic, Energetic and Construction Engineering, Higher Technical School of Engineering, University of Huelva, 21819 Palos de la Frontera, Huelva, Spain. ${ }^{3}$ Géosciences Environnement Toulouse (GET), Université de Toulouse, CNRS, IRD 14 avenue Edouard Belin, 31400 Toulouse, France. ${ }^{4}$ GeoBioTec Research Unit - Department of Geosciences, Campus de Santiago, $3810-193$ Aveiro, Portugal.

SN Applied Sciences (2019) 1:824 | https://doi.org/10.1007/s42452-019-0856-y 
Pollution from abandoned mines is one of the most serious and widespread causes of surface water degradation [35], which is difficult to solve due to the high economic costs required for remedial action (Commonwealth of Pennsylvania [6] in Grande et al. [13]).

In the area studied, the occurrence of AMD phenomena in rivers that flow into reservoirs geared towards urban supply means that waters arrive with low $\mathrm{pH}$ and high metal and sulphate load, as in the case of the Meca River that collects its waters from the Tharsis Mining Complex (Fig. 1), creating a unique scenario extraordinarily affected by acidity, sulphates and metal load $[9,11,16,18,28-30]$.

The Tharsis Mining Complex is responsible for the maximum levels of AMD pollution recorded in the Odiel basin [31]. The total area of tailings from this mining complex is 79.81 ha [25], which result from the superposition of various residues left by mining activities over a period of more than 2000 years, and characterised by the total non-existence of restoration and consequently by being a constant source of acid leachate that pollutes the waters of the Meca River, and later the El Sancho reservoir, a scenario widely studied by authors such as Cerón et al. [5], Grande et al. [17], Santisteban et al. [28, 30] and Sarmiento [31].

\subsection{Site description}

Tharsis is one of the historical mining areas from the Iberian Pyrite Belt (IPB), located in SW Spain (Fig. 1). The Iberian Pyrite Belt (IPB) extends from north of Seville-in
Spain - to southern of Portugal, constituting a region known for its large massive sulphide ore deposits [26].

The IPB represents a paradigmatic metallogenic region, characterised by its antiquity (more than 5000 years), economic relevance (more than $1700 \mathrm{Mt}$ of sulphide ore) and environmental contamination related to the mining legacy (one of the largest accumulations of pyritic wastes in the World) (e.g. Davis et al. [8]; Sanchez-Espana et al. [27]).

Specifically, the Tharsis mining district comprises one of the largest ore bodies in the Iberian Pyrite Belt, with more than $100 \mathrm{Mt}$ of estimated resources [7]. Presently, the mines are abandoned, but the environmental legacy continues.

The main mineralisation occurring in the Tharsis Mining Complex is sulphides represented by massive pyrite (more than $90 \%$ of the sulphide mass), followed by chalcopyrite, sphalerite and galena. Textural characteristics of the sulphides are variable, but most of the massive sulphides are monotonous fine-grained pyrite, often framboidal and colloform. The grains are usually fractured and brecciated [32], which promote reactivity and enhance dissolution. Gangue includes abundant quartz and aluminium silicates (mainly chlorite), with minor amounts of carbonates.

\subsection{Geological framework}

The Meca River, which receives the contaminated water by the Tharsis Mining Complex, is located in the IPB, in the southwest of Spain (Fig. 1). It runs from Seville in southern Spain to the west coast of Portugal and contains numerous

Fig. 1 Location map

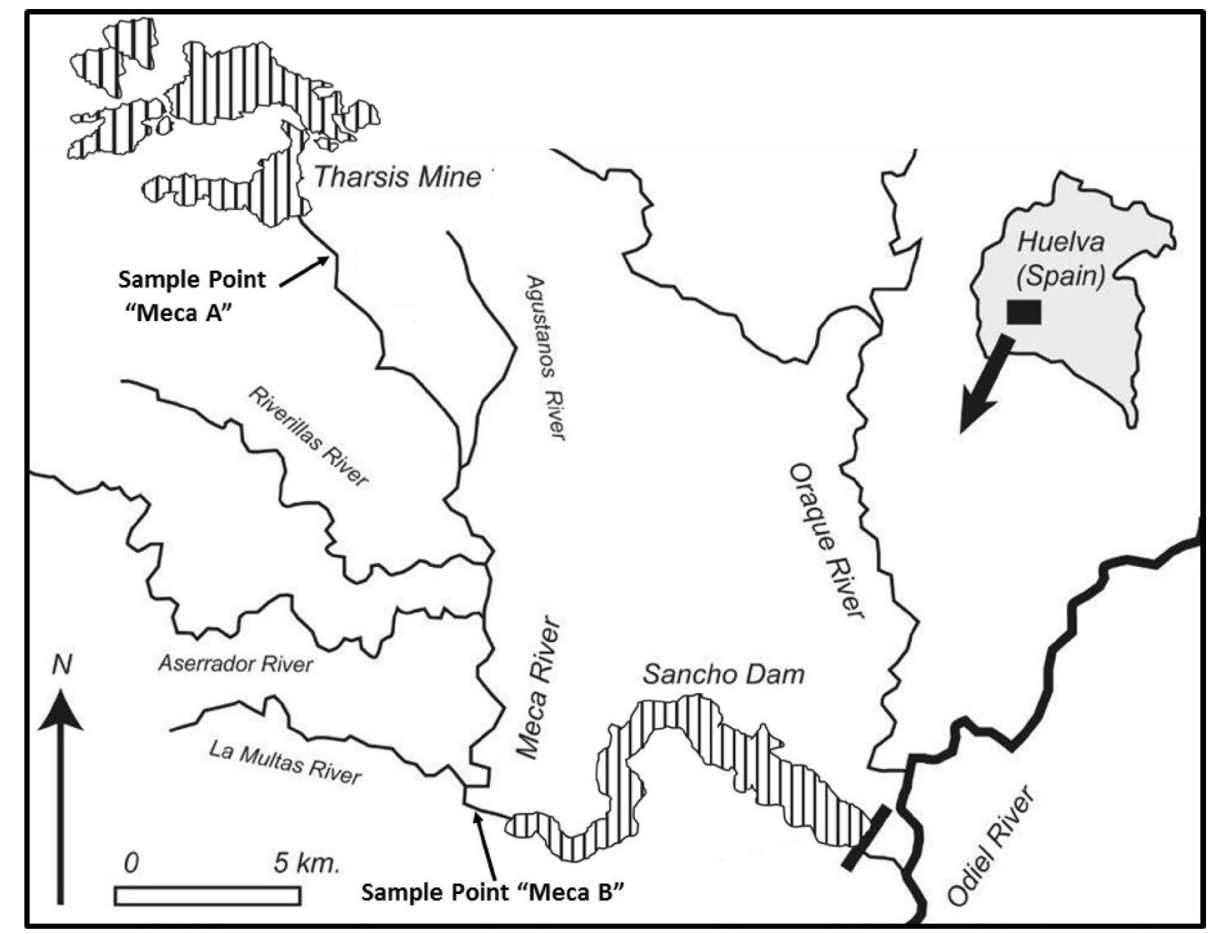


Palaeozoic massif sulphide deposits (mainly $\mathrm{Cu}, \mathrm{Pb}$ and $\mathrm{Zn}$ ), the largest in the world according to Sáez et al. [26].

The IPB reveals a highly complex lithology with many different types of rock that vary greatly in their spatial and temporal distribution. Essentially, there are three major units from up unit to the basal unit: the Culm group, the Volcano-Sedimentary Complex (VSC) and the Devonian prevolcanic sediments of the Phyllite-Quartzite Group (PQ group).

The Culm group comprises the sedimentary and postvolcanic rocks of the IPB [22]. Petrographic studies reveal that fragments of sedimentary and volcanic origin are the major lithic components of the Culm turbidite sediment.

The VSC is the most metallogenically important unit. It consists of a heterogeneous sedimentary series with interbedded magmatic rocks of varying nature and composition. Among sedimentary rocks, those of detrital and volcanoclastic origin predominate. The presence of common chemical sedimentary rocks may also be observed, as they are massive sulphides, manganese jaspers and some discontinuous levels of fossiliferous limestones [26].

The PQ group has a minimum thickness of $2000 \mathrm{~m}$, and its lithostratigraphic features are the same throughout the whole IPB, except near the top where some differentiation is observed in various places. Most of the stratigraphic column units consist of dark shales (grey to black) with fine sandstone layers [23].

\section{Objectives}

The maximum contribution of pollutants from the dump to the river courses takes place during the rainy torrential period [19]. Once the hydrochemistry between the sampling points has been studied, the objective is to characterise the processes which govern the precipitation-dissolution phenomena along the analysed river by applying graphic statistical tools, such as autocorrelation functions, cross-correlation functions and time evolution graphics, as well as computerised geochemical modelling tools.

\section{Materials and methods}

\subsection{Sampling and analysis}

A spatial and time network of sampling points was created and measured with two monitoring stations: the first (MECA A) is located at the end of the last tailing that discharges water into the Meca River, and the second (MECA $B$ ) is located downstream of the former at a distance of $14,165 \mathrm{~m}$ (Fig. 1). Point $B$ is located immediately above the flood limit of the Sancho reservoir (receiving environment)
(Fig. 1). Sampling days were scheduled for a date in which precipitation intensity would be very high, so observations of the system would be undertaken under high flow conditions. Precipitation data were provided by the National Meteorological Institute of Spain and correspond to the Tharsis Mining Complex.

The in situ sampling of water and measurements was addressed simultaneously at both points by two teams over $24 \mathrm{~h}$, from $4.00 \mathrm{pm}$ on 11 May 2016 until $4.00 \mathrm{pm}$ the next day.

The $\mathrm{pH}$, the most representative physico-chemical parameter that defines the level of AMD pollution in mining watercourses, was measured. The equipment used was a CRISON MM40. Before use, electrodes were calibrated and tested for accuracy, according to the manufacturer's instructions.

Two samples were taken in 100-mL polyethylene containers from each site. A sample for trace metals was acidified with $\mathrm{HNO}_{3} 65 \%$ Merck Suprapur to prevent metal precipitation. The other sample was kept un-acidulated for the subsequent sulphate analysis. After collection, samples were immediately refrigerated, placed in the dark and stored at $4{ }^{\circ} \mathrm{C}$ until analysis.

Sulphate was measured by photometry, using a $\mathrm{MACH}-$ ERY-NAGEL PF-11 photometer. Metal and As concentrations were determined using inductively coupled plasma optical emission spectrometry (ICP-OES) and inductively coupled plasma mass spectrometry (ICP-MS).

All reagents used were of analytical grade or higher, from Merck or Panreac. AA standard solutions certified by Panreac were used. The ultrapure water used was produced with Milli-Q, a water purification system.

International certified reference materials were analysed at the beginning and end of each batch of samples. Internal control standards were analysed every ten samples, and a duplicate was run for every ten samples. Reference standards were within $10 \%$ of certified values. The precision of all analyses was always within $5 \%$.

\subsection{Statistical methods}

The data obtained underwent initial graphic processing and subsequent statistical processing using Statgraphics Centurion XVII software.

Time series analyse the evolution throughout time of a given magnitude. In this case, the considered parameters are precipitation and variations induced by it in the water chemical composition to determine possible relationships between both of them.

Autocorrelation function corresponds to the values for an ' $x$ ' variable at given times with those corresponding to an' $x$ ' at previous times in order to know the system inertia. This function measures the existing correlation between 
the values given by the variable for a ' $t$ ' instant and the ' $t+k$ ' instant, where ' $k$ ' is the delay or time passed between one observation and the following [4].

Cross-correlation function estimates the existing correlation between a time series at a ' $t$ ' time and a second series at a ' $t+k^{\prime}$ instant as the function of delay or differential time ' $k$ '.

\subsection{Geochemical modelling}

For the geochemical modelling of the data obtained, the computer program PHREEQC (version 2.7, [24]) was used, which the parameters $\mathrm{pH}, \mathrm{Eh}, \mathrm{T}$ and OD were determined in the field and the concentrations of the major and trace elements analysed in the laboratory. Based on this information and using the known thermodynamic reactions and data (such as $\Delta G, \Delta H$ or Ks), included in the program database, PHREEQC provides geochemical information on saturation indices of mineral phases. These indices give information about the degree of supersaturation, equilibrium or subsaturation of the different mineral phases in the solution. The saturation indices provided by the program indicate supersaturation (tendency to precipitate) if positive $(\mathrm{SI}>0)$ or subsaturation (tendency to dissolve) if negative $(\mathrm{SI}<0)$.

The database used for this study was WATEQ4F, which is frequently used in acid mine waters [1].

\section{Results and discussion}

Time evolution graphs of sampling points $A$ and $B$ were made for the analysed metals by entering the $\mathrm{pH}$ variable and the precipitation in this sampling time to provide a more thorough study of them (Figs. 2 and 3). It can be seen how both points report typical characteristics of AMD media, with significantly lower values corresponding to impact indicators at point $B$ than at point $A$. Note that for a better visualisation of the time evolution of the variables within the same chart, their values appear adjusted to exact multiples.

At point $A$, there is a decrease in the concentration of the elements with a small inflection at around $9.00 \mathrm{pm}$ in response to the precipitation that fell in the previous hours, with As standing out as having the greatest decrease. On the whole, in the period between $9.00 \mathrm{pm}$ on the first day of sampling and $12.00 \mathrm{pm}$ on the second day of sampling, all elements gradually increased their values, with small inflections observed at $7.00 \mathrm{pm}$ for As and Zn. In response to the precipitation which fell at $12.00 \mathrm{pm}$ on the second day of sampling, a sharp drop in all the elements analysed was observed $1 \mathrm{~h}$ later.

At point $\mathrm{B}$, a shorter response time to the precipitation can be observed, with greater sensitivity to variations. Particularly noteworthy are the major peaks of inflection observed for Fe and As at around $2.00 \mathrm{am}$ and at $3.00 \mathrm{pm}$ on the second day of sampling.

These observed variations in the concentration of the parameters analysed at both sampling points may be due to the fact that water is collected from the tailings at sampling point $A$, with a high residence time in the interior, while surface runoff waters are collected at point $B$, with immediate response to precipitation.

Special mention should be made of the $\mathrm{pH}$ variable, which at point $A$ shows an almost flat evolution over time, while at point $B$ it shows variations of up to $2 \mathrm{pH}$ units.

We can consider that at point $A$ the waters are not very evolved from a hydrochemical point of view. All the variables offer a characteristic response in AMD media caused by the dilution induced by the rainfall producing

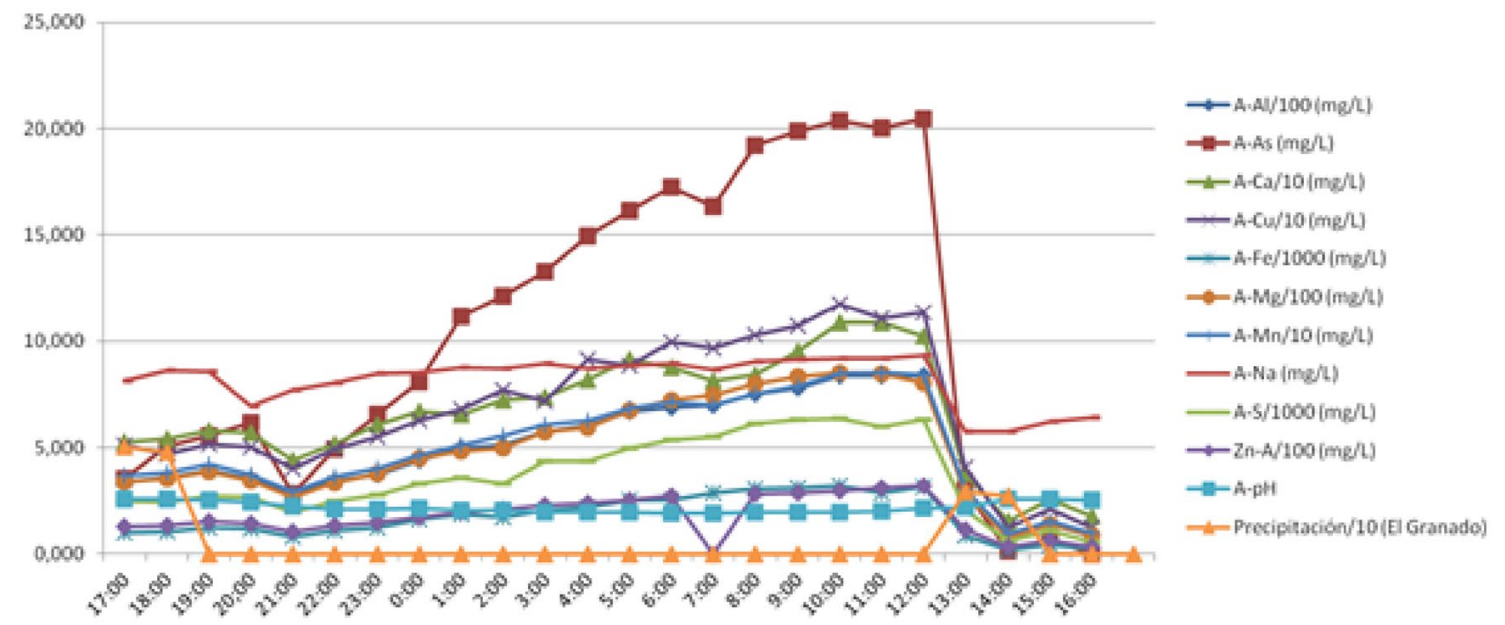

Fig. 2 Time evolution graph for sampling point $A$ 


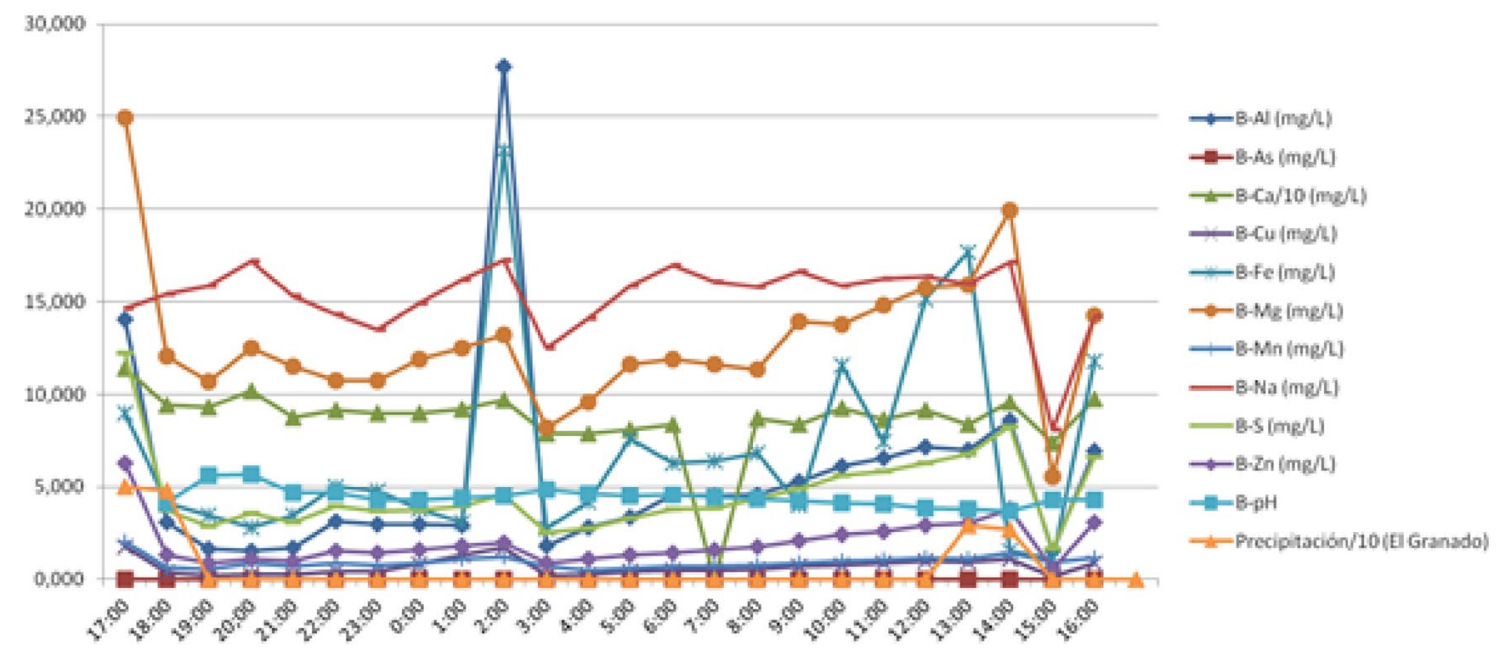

Fig. 3 Time evolution graph for sample point B

a temporary decrease in the concentration of the pollutant load in relation to the peaks of rain. These variations are more visible at point $A$ than at point $B$.

The statistical summary (Table 1 ) shows for the rain variable a maximum of 4.8 corresponding to a rainfall of $48 \mathrm{~L} / \mathrm{m}^{2}$ in $1 \mathrm{~h}$, exactly at the beginning of the monitoring period. This rainfall is extraordinarily high for the region under study and accounts for almost one twelfth of the total rainfall for a normal hydrological year, which hovers around $600 \mathrm{~mm} /$ year.

The $\mathrm{pH}$ values are notably lower at point $A$ than at point $B$, with the average value at point $B$ doubling the value at point $A$, where they reach minimum values of 1.9 and maximums of less than 2.6. Meanwhile, the maximum at point $A$ reaches 5.68 , while the minimum does not fall below 3.6. The kurtosis also almost doubles its value at $A$ with respect to $B$.

It can be observed that all the elements analysed at point $\mathrm{A}$, with the exception of $\mathrm{Na}$, have higher average values than at point $B$.

$\mathrm{S}$ and Fe stand out for their high concentrations, with maximums of $6362.89 \mathrm{mg} / \mathrm{L}$ and $3202 \mathrm{mg} / \mathrm{L}$, respectively. $\mathrm{Al}(838.61 \mathrm{mg} / \mathrm{L})$ and $\mathrm{Mg}(854.186 \mathrm{mg} / \mathrm{L})$ also stand out for their high values, as do $\mathrm{Zn}$ and $\mathrm{Cu}$, which have maximums of $317.59 \mathrm{mg} / \mathrm{L}$ and $117.30 \mathrm{mg} / \mathrm{L}$, respectively. The rest of the analysed elements present values of under $100 \mathrm{mg} / \mathrm{L}$.

The lowest values observed are $\mathrm{Cu}, \mathrm{Mg}$ and $\mathrm{Mn}$, with minimums lower than $1 \mathrm{mg} / \mathrm{L}$.

The autocorrelation functions (ACF) of the analysed elements (Figs. 4 and 5) show that for all cases, point

Table 1 Statistical summary for sample points A and B

\begin{tabular}{|c|c|c|c|c|c|c|c|c|c|c|c|}
\hline & Ta-A $\left({ }^{\circ} \mathrm{C}\right)$ & $\mathrm{pH}-\mathrm{A}$ & $\begin{array}{l}\text { Al-A } \\
(\mathrm{mg} / \mathrm{L})\end{array}$ & $\begin{array}{l}\text { Ca-A } \\
(\mathrm{mg} / \mathrm{L})\end{array}$ & $\begin{array}{l}\mathrm{Cu}-\mathrm{A} \\
(\mathrm{mg} / \mathrm{L})\end{array}$ & $\begin{array}{l}\mathrm{Fe}-\mathrm{A} \\
(\mathrm{mg} / \mathrm{L})\end{array}$ & $\begin{array}{l}\mathrm{Mg}-\mathrm{A} \\
(\mathrm{mg} / \mathrm{L})\end{array}$ & $\begin{array}{l}\mathrm{Zn}-\mathrm{A} \\
(\mathrm{mg} / \mathrm{L})\end{array}$ & $\begin{array}{l}\mathrm{Mn}-\mathrm{A} \\
(\mathrm{mg} / \mathrm{L})\end{array}$ & $\begin{array}{l}\mathrm{Na}-\mathrm{A} \\
(\mathrm{mg} / \mathrm{L})\end{array}$ & $\begin{array}{l}\text { S-A } \\
(\mathrm{mg} / \mathrm{L})\end{array}$ \\
\hline Mean & 15.45 & 2.13 & 480.46 & 65.77 & 67.01 & 1698.75 & 483.55 & 184.51 & 49.91 & 8.17 & 3464.90 \\
\hline Standard deviation & 1.30 & 0.22 & 238.96 & 27.08 & 32.26 & 978.12 & 246.94 & 87.51 & 23.67 & 1.15 & 1993.50 \\
\hline Coefficient of variation & 0.08 & 0.10 & 0.50 & 0.41 & 0.48 & 0.58 & 0.51 & 0.47 & 0.47 & 0.14 & 0.58 \\
\hline Minimum & 13.82 & 1.90 & 74.03 & 15.42 & 12.32 & 184.33 & 76.15 & 33.17 & 9.28 & 5.72 & 24.78 \\
\hline \multirow[t]{2}{*}{ Maximum } & 17.86 & 2.60 & 838.61 & 108.88 & 117.30 & 3202.16 & 854.19 & 317.60 & 85.10 & 9.31 & 6362.89 \\
\hline & $\mathrm{Ta}-\mathrm{B}\left({ }^{\circ} \mathrm{C}\right)$ & $\mathrm{pH}-\mathrm{B}$ & $\begin{array}{l}\text { Al-B } \\
(\mathrm{mg} / \mathrm{L})\end{array}$ & $\begin{array}{l}\text { Ca-B } \\
(\mathrm{mg} / \mathrm{L})\end{array}$ & $\begin{array}{l}\text { Cu-B } \\
(\mathrm{mg} / \mathrm{L})\end{array}$ & $\begin{array}{l}\mathrm{Fe}-\mathrm{B} \\
(\mathrm{mg} / \mathrm{L})\end{array}$ & $\begin{array}{l}\mathrm{Mg}-\mathrm{B} \\
(\mathrm{mg} / \mathrm{L})\end{array}$ & $\begin{array}{l}\mathrm{Zn-B} \\
(\mathrm{mg} / \mathrm{L})\end{array}$ & $\begin{array}{l}\mathrm{Mn}-\mathrm{B} \\
(\mathrm{mg} / \mathrm{L})\end{array}$ & $\begin{array}{l}\mathrm{Na}-\mathrm{B} \\
(\mathrm{mg} / \mathrm{L})\end{array}$ & $\begin{array}{l}\text { S-B } \\
(\mathrm{mg} / \mathrm{L})\end{array}$ \\
\hline Mean & 15.86 & 4.42 & 5.56 & 8.98 & 0.70 & 6.98 & 12.93 & 1.99 & 0.95 & 15.22 & 47.01 \\
\hline Standard deviation & 0.43 & 0.50 & 5.65 & 0.86 & 0.46 & 5.54 & 3.86 & 1.25 & 0.33 & 1.99 & 22.71 \\
\hline Coefficient of variation & 0.03 & 0.11 & 1.02 & 0.10 & 0.66 & 0.79 & 0.30 & 0.63 & 0.35 & 0.13 & 0.48 \\
\hline Minimum & 15.11 & 3.61 & 1.55 & 7.38 & 0.15 & 1.11 & 5.56 & 0.55 & 0.50 & 8.07 & 16.63 \\
\hline Maximum & 16.45 & 5.68 & 27.70 & 11.40 & 1.79 & 23.19 & 24.94 & 6.25 & 2.02 & 17.25 & 122.00 \\
\hline
\end{tabular}




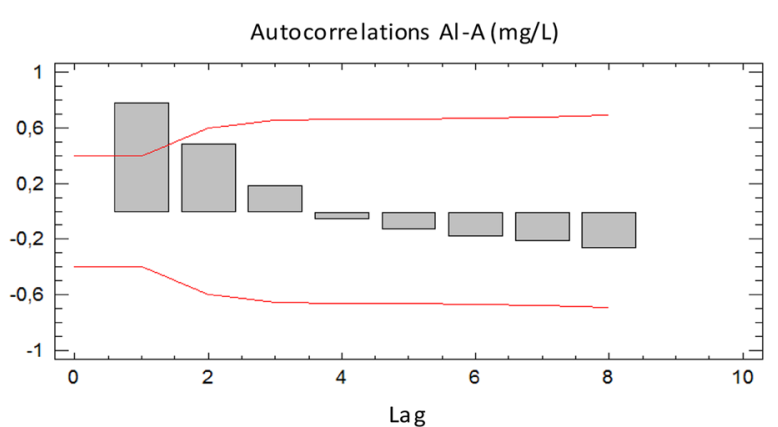

Autocorrelations Ca-A (mg/L)

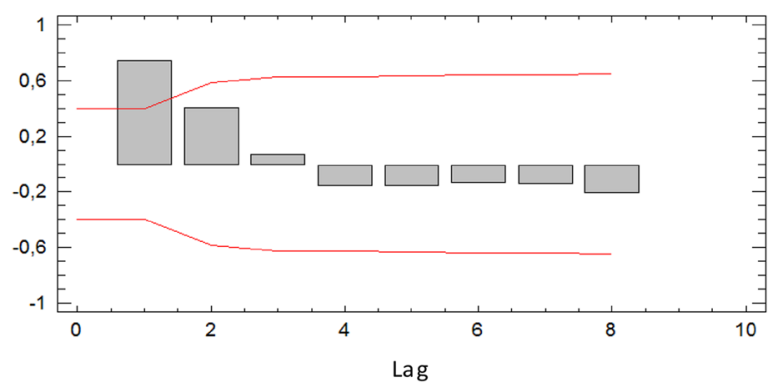

Autocorrelations $\mathrm{Cu}-\mathrm{A}(\mathrm{mg} / \mathrm{L})$

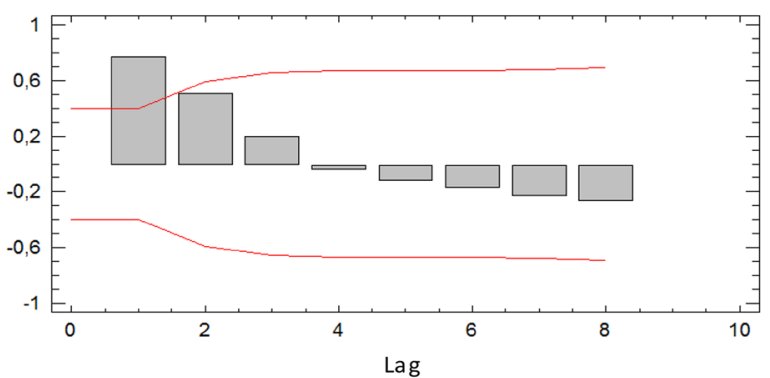

Autocorrelations Fe-A (mg/L)

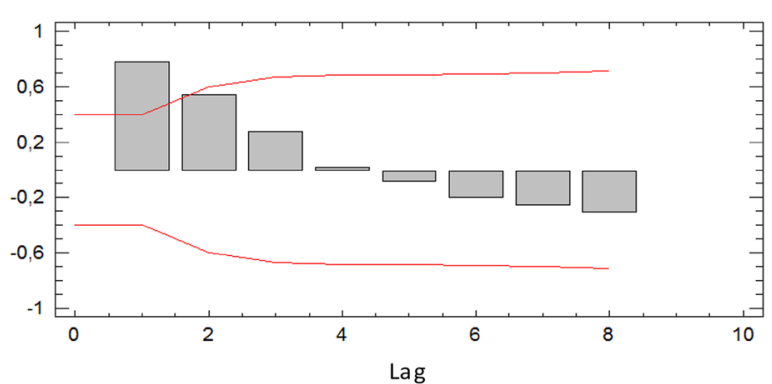

Autocorrelations $\mathrm{Zn}-\mathrm{A}$ (mg/L)

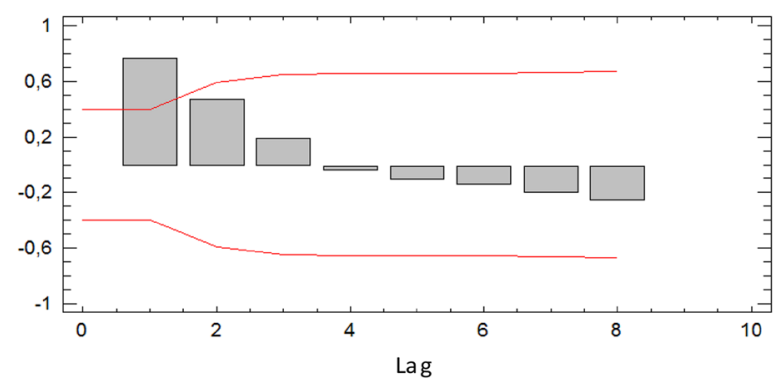

Autocorrelations $\mathrm{Mg}-\mathrm{A}(\mathrm{mg} / \mathrm{L})$

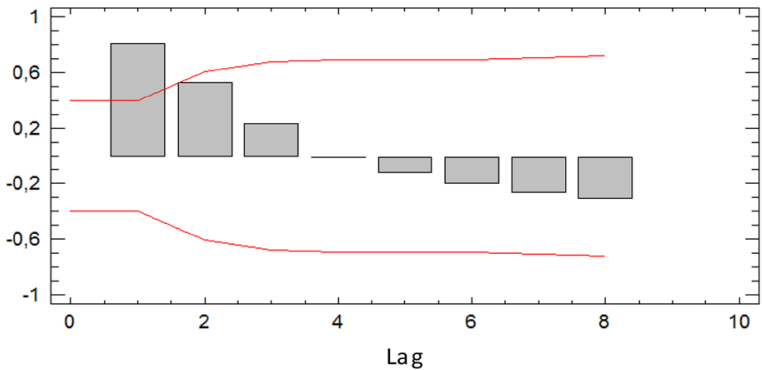

Autocorrelations $\mathrm{Mn}-\mathrm{A}(\mathrm{mg} / \mathrm{L})$

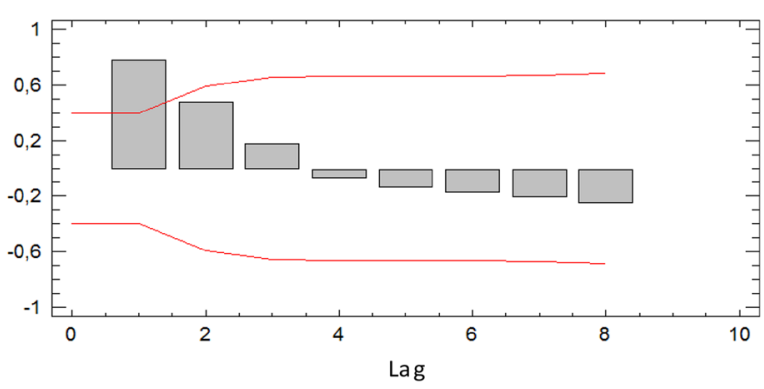

Autocorrelations $\mathrm{Na}-\mathrm{A}(\mathrm{mg} / \mathrm{L})$

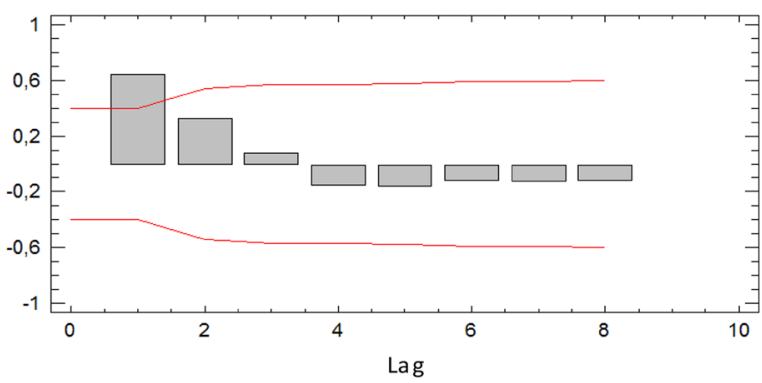

Autocorrelations S-A (mg/L)

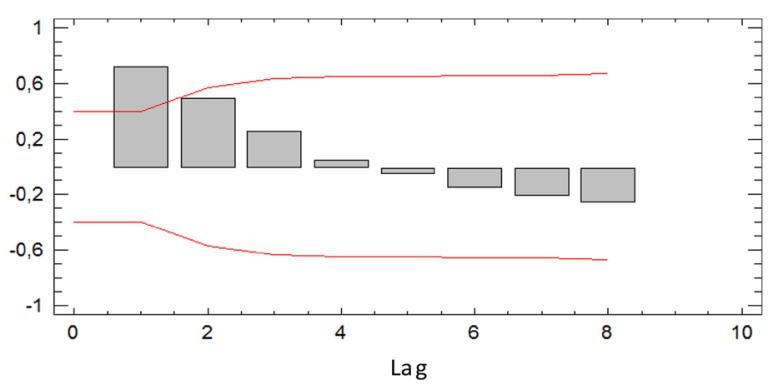

Fig. 4 Autocorrelations for the variables under study at sampling point $A$

\section{SN Applied Sciences}

A SPRINGER NATURE journal 
Cross correlations Al-B (mg/L) - Al-A (mg/L)

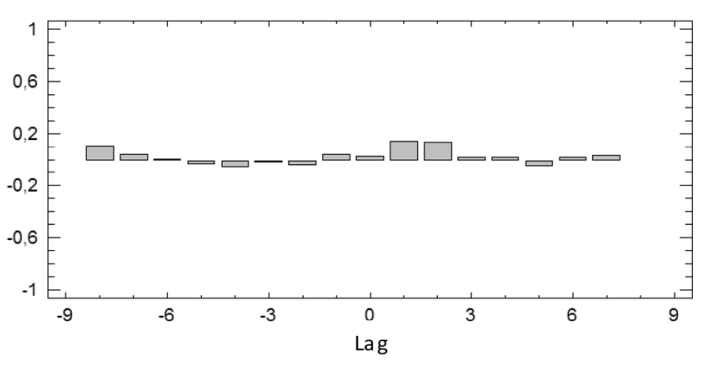

Cross corre lations Ca-B (mg/L) - Ca-A $(\mathrm{mg} / \mathrm{L})$

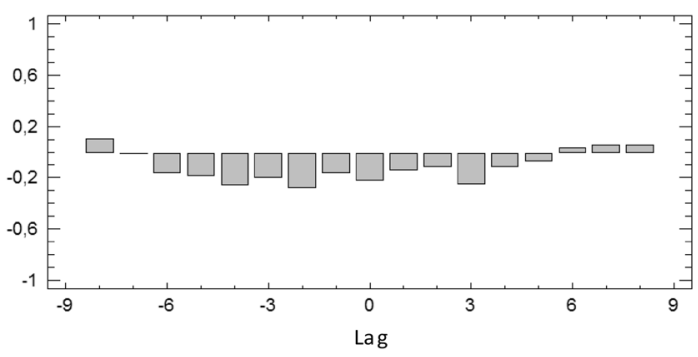

Cross correlations Cu-B (mg/L) - Cu-A (mg/L)

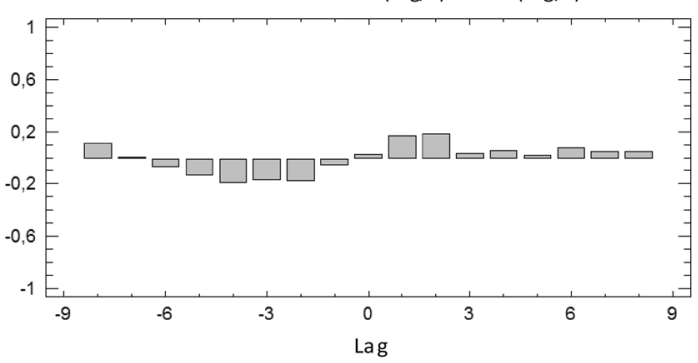

Crosscorrelations Fe-B (mg/L) - Fe-A (mg/L)

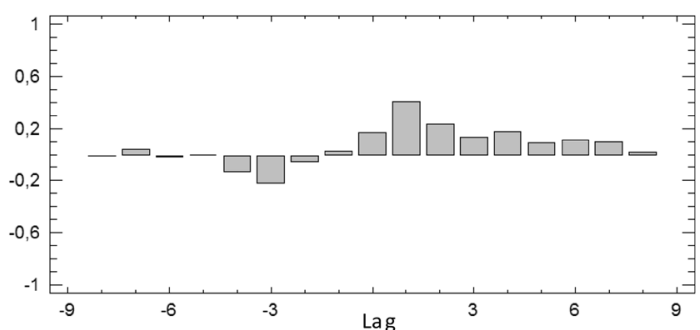

Autocorrelations $\mathrm{Zn}-\mathrm{A}(\mathrm{mg} / \mathrm{L})$

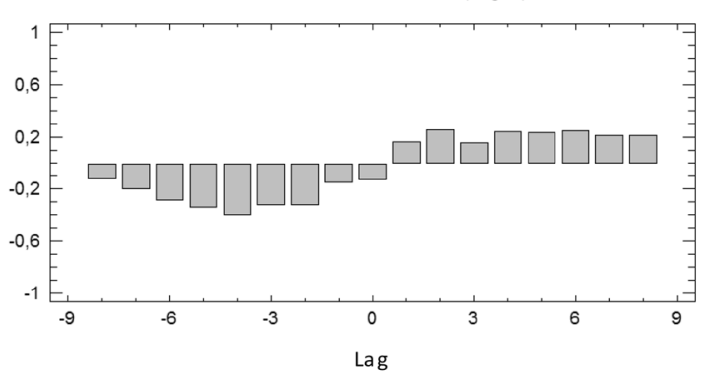

Cros s correlations $\mathrm{Mg}-\mathrm{B}(\mathrm{mg} / \mathrm{L})-\mathrm{Mg}-\mathrm{A}(\mathrm{mg} / \mathrm{L})$

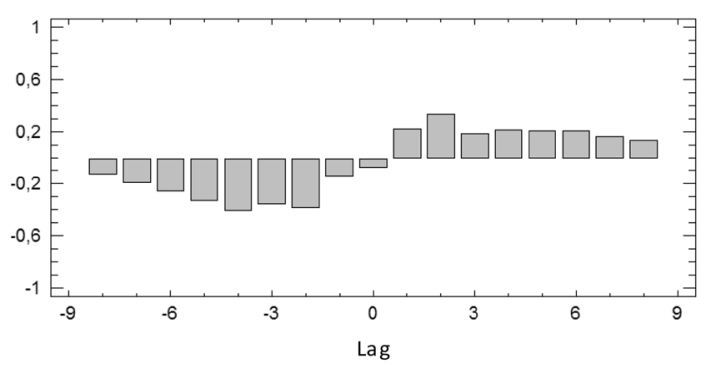

Cros s corre lations $\mathrm{Mn}-\mathrm{B}(\mathrm{mg} / \mathrm{L})-\mathrm{Mn}-\mathrm{A}(\mathrm{mg} / \mathrm{L})$

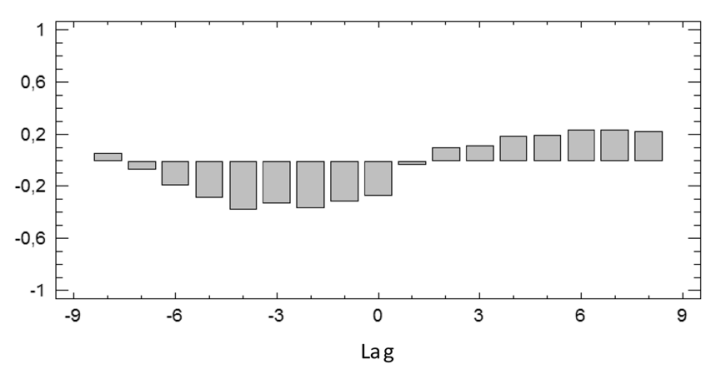

Crosscorrelations $\mathrm{Na}-\mathrm{B}(\mathrm{mg} / \mathrm{L})-\mathrm{Na}-\mathrm{A}(\mathrm{mg} / \mathrm{L})$

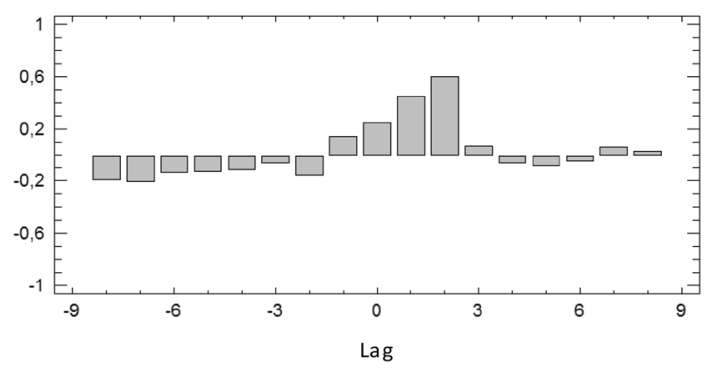

Correlaciones Cruzadas Estimadas para S_B_mg_L_con S_A_mg_L_

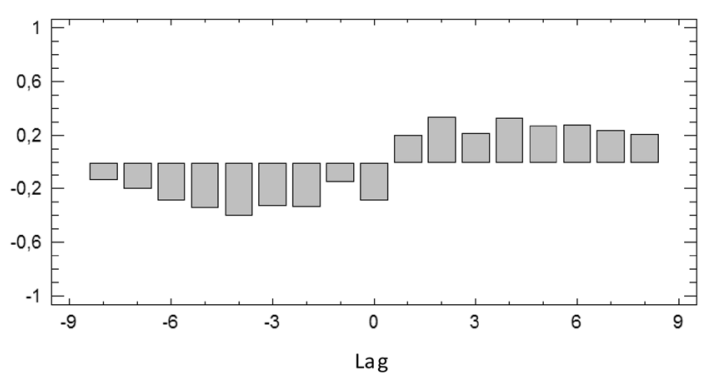

Fig. 5 Autocorrelations for the variables under study at sampling point B 
A presents higher values of autocorrelation than point $B$ does, with correlation maximums of 0.8 , except for $\mathrm{S}, \mathrm{Na}$ and $\mathrm{Zn}$, which show maximums around 0.7. All the elements analysed have a memory of less than $2 \mathrm{~h}$. However, at point $B$ no significant autocorrelations are observed for any element.

The cross-correlation functions (CCF) were determined by taking the value of each variable at point $A$ as the input and the value of the same variable at point $B$ as the output (Fig. 6). These functions show discrete correlation coefficients for the elements analysed at both sampling points. $\mathrm{Na}$ and Fe present the highest correlation coefficients, with values around 0.6 and 0.5 , respectively, and in both cases a lag of less than $3 \mathrm{~h}$. The other elements present minor and insignificant correlations, with $\mathrm{S}, \mathrm{Zn}, \mathrm{Mg}$ and $\mathrm{Mn}$ having values of around 0.3 and a memory of under $3 \mathrm{~h}$ in all cases, due to the sensitivity of the environment to the rain stimulus.

The CCF and ACF made it possible to determine the 'system memory', with it being set at less than $3 \mathrm{~h}$. This response time against external stimuli, such as rain in this case, already observed in the spatial evolution graphs, was contrasted by the autocorrelation and crosscorrelation functions. Theses functions applied to the series studied show the value for correlations between each variable on 1 day and the same variable on the previous days. Theses tools have been widely used for hydrochemical characterisation [10,12,14], which allows a numerical estimation of the resistance of a mass of water, to a change in its physico-chemical characteristic, to an external stimulus [15]. In this sense, the present results highlight the resistance to physical-chemical changes of water until 3 days after the external stimuli act.

The mineral saturation indices were calculated to determine the possible mineral species which could theoretically be precipitated from the waters under study, in the samples taken at both sampling points this was done, before and after the torrential rainfall in the 3-h interval, thereby matching the previously determined response time of the system. These indices allowed us to infer the possible secondary mineral phases which would precipitate from these acid waters. The precipitation of a mineral from a solution may be estimated by comparing the saturation index, so if this index is positive $(\mathrm{SI}>0)$, mineral precipitation could occur.

The results of the calculations show that the acid drainage is totally sub-saturated $(\mathrm{SI}<0)$ before the rainfall at both sampling points, while after the rainfall, the downstream sampling point (point $\mathrm{B}$ ) is oversaturated $(\mathrm{SI}>0$ ) with respect to magnetite, haematite and goethite.
Meanwhile, other phases, such as jarosite, are sub-saturated $(\mathrm{SI}<0)$.

According to theoretical stability [34], jarosite is formed solely in acidic and oxidising media under conditions of high supersaturation, which may explain the absence of jarosite precipitation in our study medium. In addition, the presence of high sulphate concentrations also means that jarosite does not precipitate and remains dissolved [2], as is our case.

The source of the possible iron oxide precipitation may be due to the oxidation and hydrolysis of the $\mathrm{Fe}^{2+}$ released by the pyrite dissolving, which can occur at times of greater water dilution [2], as is the case of the scenario under study.

The minerals that are most commonly formed from acid mine drainage media are ferrihydrite, jarosite and schwertmannite [3]. The precipitation of one or another compound depends on the availability of ions, but also on $\mathrm{pH}$ values. However, these compounds are metastable and may undergo hydrolysis processes leading to the formation of goethite or haematite, releasing part of the $\mathrm{Fe}$, sulphate and As retained in the other Fe compounds [20]. This fact may justify the possible theoretical precipitation of iron oxides determined in this study.

\section{Conclusions}

The graphic statistical treatment allowed us to characterise two clearly different scenarios in response to the degree of evolution experienced by the waters between the sampling points.

By means of the autocorrelation functions, we can explain how the phenomenon of 'hydrochemical inertia' for this scenario is much greater at point $A$ than at point $B$ due to the proximity to the source focus, in addition to the shortage of other chemo-modifying stimuli at this point.

The compositional differences between both points are fundamentally due to two phenomena: the first is a consequence of the proximity to the pollutant source, where the waters have not yet evolved, while the second is due to the development of hydrolysis processes in areas further away from the source focus. These hydrolysis processes have been verified through the study of the saturation indices which have shown how the possible mineral species that could precipitate from these already mature waters are coherent with the hydrolysis processes described in the literature. 
Cross correlations Al-B (mg/L) - Al-A (mg/L)

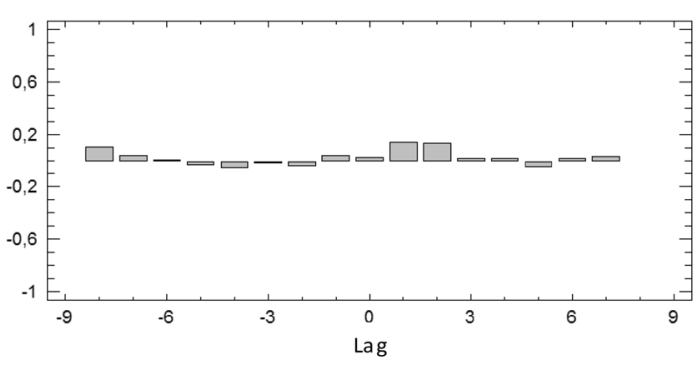

Cross correlations Ca-B (mg/L) - Ca-A (mg/L)
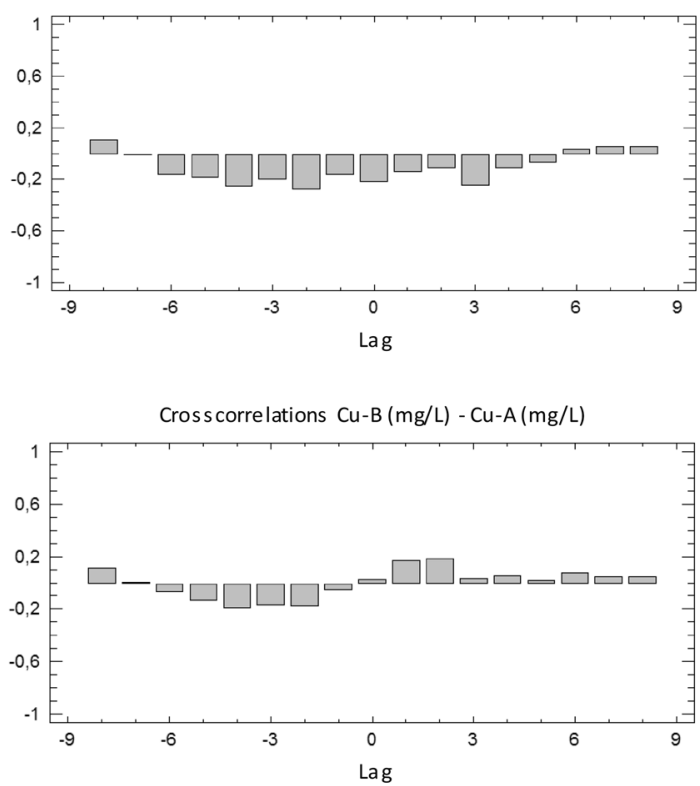

Crosscorrelations Fe-B (mg/L) - Fe-A (mg/L)

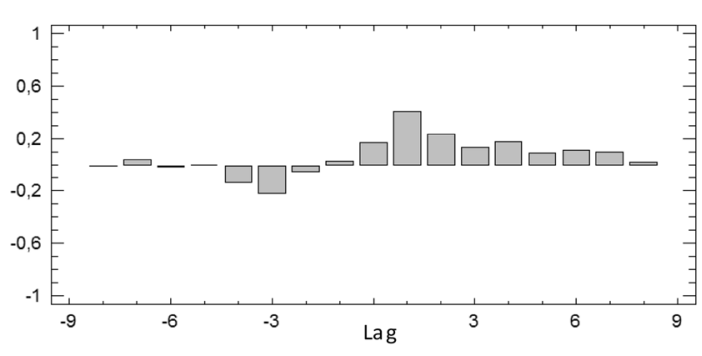

Autocorrelations $\mathrm{Zn}-\mathrm{A}(\mathrm{mg} / \mathrm{L})$

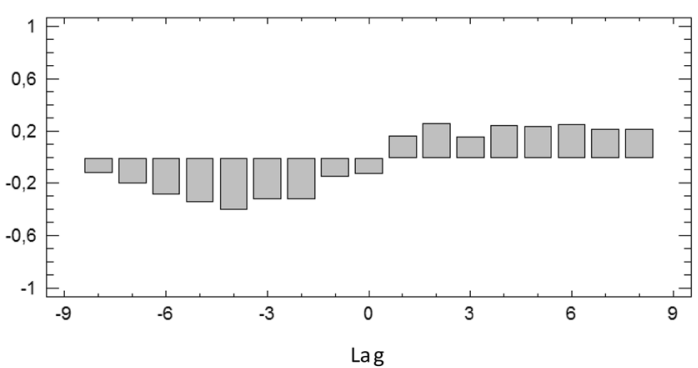

Cros s corre lations $\mathrm{Mg}-\mathrm{B}(\mathrm{mg} / \mathrm{L})-\mathrm{Mg}-\mathrm{A}(\mathrm{mg} / \mathrm{L})$

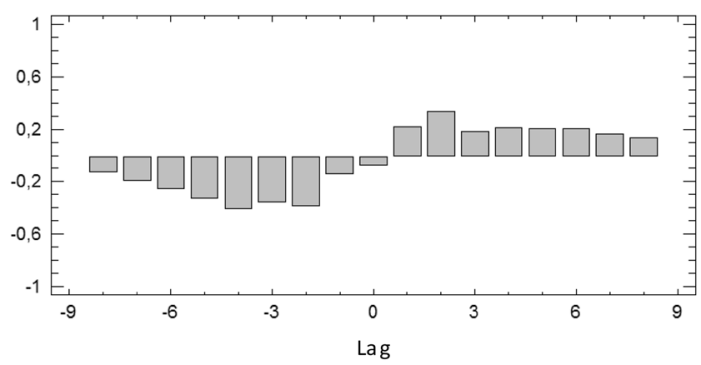

Crosscorrelations $\mathrm{Mn}-\mathrm{B}(\mathrm{mg} / \mathrm{L})-\mathrm{Mn}-\mathrm{A}(\mathrm{mg} / \mathrm{L})$

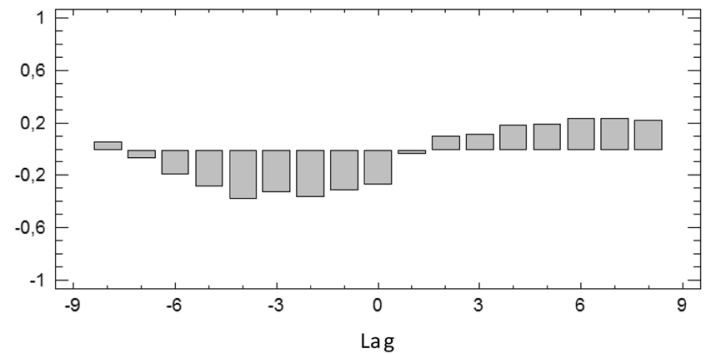

Crosscorrelations $\mathrm{Na}-\mathrm{B}(\mathrm{mg} / \mathrm{L})-\mathrm{Na}-\mathrm{A}(\mathrm{mg} / \mathrm{L})$

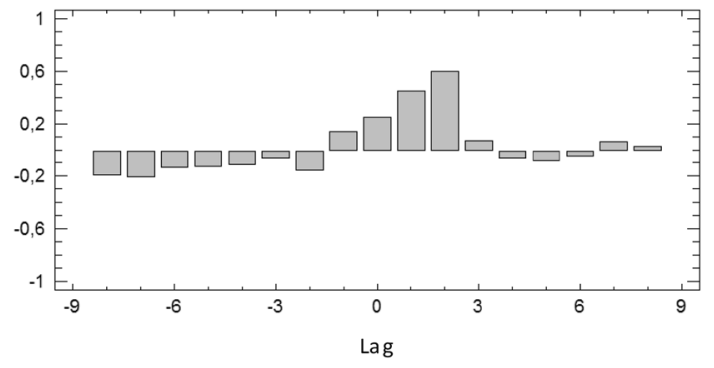

Correlaciones Cruzadas Estimadas para S_B_mg_L_con S_A_mg_L_

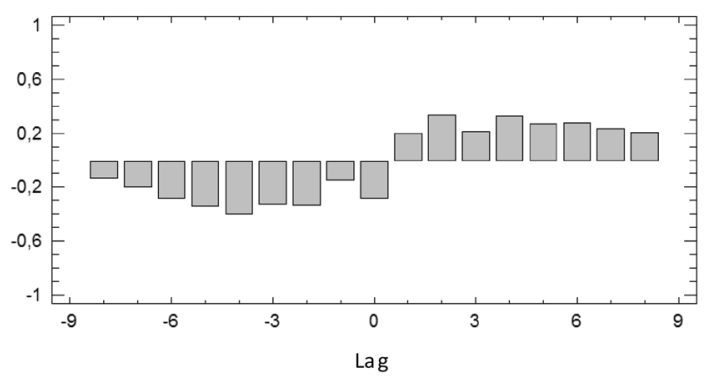

Fig. 6 Cross-correlations for the variables under study in sampling points $A$ and $B$ 
Acknowledgements This study was supported by the Andalusian Autonomous Government Excellence Projects (Spain), Project P06-RNM-02167.

\section{Compliance with ethical standards}

Conflict of interest The authors declare that they have no competing interests.

\section{References}

1. Ball JW, Nordstrom D (2001) User's manual for WATEQ4F with revised thermodynamic database and test cases for calculation speciation of major, trace and redox elements in natural waters. In: US Geological Survey (ed) Water-Resources Investigation Report. Menlo Park, CA

2. Barral S (1989) Precipitados de hierro en medios sulfato-ácidos que resultan de la alteración de anfibolitas ricas en sulfatos. Cuaderno Lab. Xéolóxico de Laxe Coruña 14:29-42

3. Bigham JM, Schwertmann U, Traina SJ, Winland RL, Wolf M (1996) Schwertmannite and the chemical modeling of iron in acid sulfate waters. Geochim Cosmochim Acta 60(12):2111-2121

4. Bisquerra R (1989) Conceptual introduction to Multivariance Analysis (Spanish), (808p.). Promociones y Publicaciones Universitarias, S.A. Barcelona, Spain

5. Cerón JC, Grande JA, de la Torre ML, Santisteban M, Valente T (2013) Impact of AMD processes on the water dams of the Iberian Pyrite Belt, overall hydrochemical characterization (Huelva, SW Spain). Water Air Soil Pollut 224(8):1-11. https:// doi.org/10.1007/s11270-013-1642-x

6. Commonwealth of Pennsylvania (1994) Water quality assessment in western Pennsylvania watershed. Department of Environmental Protection, Pennsylvania, Conference, Durango, CO

7. Conde C, Tornos F, Large R, Danyushevsky L, Solomon M (2009) Análisis de elementos traza por la LA-ICPMS en pirita de los sulfuros masivos de Tharsis (FPI). Macla 2009:63-64

8. Davis JR, Welty RA, Borrego J, Morales JA, Pendón JG, Ryan JG (2000) Rio Tinto estuary (Spain): 5000 years of pollution. Environ Geol 39(10):1107-1116

9. de la Torre ML, Sanchez-Rodas D, Grande JA, Gómez T (2010) Relationships between $\mathrm{pH}$, colour and heavy metal concentrations in the Tinto and Odiel rivers (South West Spain). Hydrol Res 41(5):406-413

10. de la Torre ML, Grande JA, Graiño J, Gómez T, Ceron T (2011) Characterization of AMD pollution in the river Tinto (SW Spain). Geochemical comparison between generating source and receiving environment. Water Air Soil Pollut 216:3-19

11. de la Torre ML, Grande JA, Santisteban M, Valente T, Borrego J, Salguero F (2013) Statistical contrast analysis of hydrochemical parameters upstream of the tidal influence in two AMD-affected rivers. Mine Water Environ 33:217-227. https://doi.org/10.1007/ s10230-013-0258-0

12. de la Torre ML, Grande JA, Santisteban M, Valente T, Borrego J, Salguero F (2014) Statistical contrast analysis of hydrochemical parameters upstream of the tidal influence in two AMD-affected rivers. Mine Water Environ 33:217-227

13. Grande JA, Beltrán R, Sáinz A, Santos JC, de la Torre ML, Borrego $J(2005)$ Acid mine drainage and acid rock drainage processes in the environment of Herrerías Mine (Iberian Pyrite Belt, Huelva-Spain) and impact on the Andevalo Dam. Environ Geol 47:185-196
14. Grande JA, Jiménez $A$, Romero $S$, de la Torre $M L$, Gómez $T$ (2010) Quantification of heavy metals from AMD discharged into a public water supply dam in the Iberian Pyrite Belt (SW Spain) using centered moving average. Water Air Soil Pollut 212:299-307

15. Grande JA, Andujar JM, Aroba J, Beltran R, de la Torre ML, Ceron JC, Gomez T (2010) Fuzzy modelling of the spatial evolution of the chemistry in the Tinto River (SW Spain). Water Resour Manag 24:3219-3235

16. Grande JA, Santisteban M, de la Torre ML, Valente T, PérezOstalé E (2013) Characterisation of AMD pollution in the reservoirs of the Iberian Pyrite Belt. Mine Water Environ 32:321330. https://doi.org/10.1007/s10230-013-0236-6

17. Grande JA, de la Torre ML, Santisteban M, Valente T, Fernández J, Pérez-Ostalé E (2015) Spatial evolution of an AMD stream in the Iberian Pyrite Belt: process characterization and control factors on the hydrochemistry. Hydrol Sci J 61(8):1503-1511. https://doi.org/10.1080/02626667.2014.983515

18. Grande JA, de la Torre ML, Valente T, Fernández JP, Borrego J, Santisteban M, Cerón JC, Sánchez-Rodas D (2015) Stratification of metal and sulphate loads in Acid Mine Drainage receiving water dams variables regionalization by cluster analysis. Water Environ Res 87(7):626-634. https://doi. org/10.2175/106143015X14212658614793

19. Grande JA, Santisteban M, de la Torre ML, Zouiten C, Viers J, Masbou J, Freydier R, Seyler P (2018) Functional model of a sulfide waste dump during torrential rain, temporal evolution of acid mine drainage in the receiving watercourse. Waste Manag (in press)

20. Gónzales MP (2012) Efectos sobre la precipitación de jarosita por adición de potasio en drenajes ácidos de mina. Universidad Internacional de Andalucía

21. Lyew D, Sheppard J (2001) Use of conductivity to monitor the treatment of acid mine drainage by sulphate-reducing bacteria. Water Res 358:2081-2086

22. Moreno C, Gonzalez F (2004) Estratigrafia, capitulo: Zona Sudportuguesa. In: Vera JA (ed) Geologia de Espana. SGE-IGME, Madrid, pp 199-222

23. Moreno C, Sequeiros $L$ (1989) The basal shaly formation of the Iberian Pyrite Belt (South Portuguese Zone): early carboniferous bitominous deposits. Paleogeogr Paleoclimatol Paleoecol 73(3/4):233-241

24. Parkhurst D, Appelo C (1999) User's guide to PHREEQC (Version 2): a computer program for speciation, batch-reaction, one-dimensional transport, and inverse geochemical calculations US Geological Survey. Water Resour Investig Rep 99:4259-4310

25. Pérez-Ostalé E (2014) Caracterización ambiental de estructuras mineras en la Faja Pirítica Ibérica como soporte metodológico de gestión territorial. Ph.D. Thesis, University of Huelva

26. Sáez R, Pascual E, Toscano M, Almodovar GR (1999) The Iberian type of volcanosedimentary massive sulfide deposits. Miner Deposita 34:549-570

27. Sánchez-España J, López-Pamo E, Santofimia E, Aduvire O, Reyes J, Barettino D (2005) Acid mine drainage in the Iberian Pyrite Belt (Odiel river watershed, Huelva, SW Spain): Geochemistry, mineralogy and environmental implications. Appl Geochem 20:1320-1356

28. Santisteban M, Grande JA, de la Torre ML, Valente T, Cerón JC (2013) Acid mine drainage in semi-arid regions, the extent of the problem in the waters of reservoirs in the Iberian Pyrite Belt (SW Spain). Hydrol Res 46:156-167. https://doi.org/10.2166/ nh.2013.086

29. Santisteban M, Grande JA, de la Torre ML, Valente T, PérezOstalé E, Cerón JC (2014) Fuzzy intelligence approach for modeling the migration of contaminants in a reservoir affected by 
AMD pollution. Mine Water Environ 34:352-360. https://doi. org/10.1007/s10230-014-0321-5

30. Santisteban M, Grande JA, de La Torre ML, Valente T, Perez-Ostalé E, Garcia-Pérez M (2016) Study of the transit and attenuation of pollutants in a water reservoir receiving acid mine drainage in the Iberian Pyrite Belt (SW Spain). Water Sci Technol 16:128-134. https://doi.org/10.2166/ws.2015.122

31. Sarmiento M, Nieto JM, Olías M, Cánovas C (2009) Hydrochemical characteristics and seasonal influence on the pollution by acid mine drainage in the Odiel river Basin SW Spain. Appl Geochem 29:697-714

32. Tornos F, Solomon M, Conde C, Spiro B (2008) Formation of the Tharsis massive sulfide deposit, Iberian Pyrite Belt: geological, lithologeochemical, and stable isotope evidence for deposition in a brine pool. Econ Geol 103:185-214
33. USEPA (1994) Acid mine drainage prediction. US Environmental Protection Agency, Office of Solid Waste, EPA530-R-94-036

34. Van Breemen N (1976) Genesis and solution chemistry of acid sulfate soils in Thailand. Center for Agricultural Publishing, Wageningen

35. Younger PL (1997) The longevity of minewater pollution, a basis for decision-making. Sci Total Environ 194-195:457-466

Publisher's Note Springer Nature remains neutral with regard to jurisdictional claims in published maps and institutional affiliations. 